drawn:-1st. That there are upwards of Ioo owners and occupiers of land in Great Britain who use sewage for the sake alone of what they can get out of it by agricultural means. 2nd. That of this number more than sixty are tenant farmers who continue to use it although they have, annually at least, the option of ceasing to do so. 3 rd. That of the latter number about five-sixths, and of the total number about three.fourths, actually pay money for the use of the sewage, either in the form of out-fall rent, unquestionable increase of land rent, or the price of occasional dressings. Nearly 4,000 acres of sewage land have been referred to, and these are in the hands of more than a hundred distinct occupiers. These occupiers may be divided into three classes:-Those who have to cleanse a certain quantity of sewage on a certain irea of land; those who may take, or leave alone, as much of a town's sewage as they please; and those who may take, or lenve alone, what sewage can be spared by others having a prior right. The first class occupies $I, 670$ acres of sewaged land, and deals with the sewage of twenty distinct sanitary districts, or a population of about 200,000 on as many as twenty-one different farms. Mr. Birch's paper will be published as a pamphlet by Messrs. Spon.

Amovg the novelties in the German book tracle for May, we notice the following scientific works:-" Teleologie und Darwinismus," Dr. Kalischer (Berlin); "Gedanken uiber die Teleologie in der Natur," v. Bärenbach (Berlin); "Reisebriefe aus Kordofan und Dar-Fur," Dr. F. Pfund (Hamburg); "Die allgemeinsten chemischen Formeln," Prof. C. Willgerodt (Heidelberg); "Der Sternhaufen $\chi$ Persei, beobachtet in der Leipziger Sternwarte von 1867-70," H. C. Vogel (Leipzig); "Die Verbreitung der Atmosphäre," M. Thiesen (Berlin); "Aus der Physik des Luftmeers," G. Münter (Herford); "Praxis der Naturgeschichte botanische, zoologische, und Akklimatisations gärten, Aquarien, \&e.," P. L. Martin (Weimar); "Atlas cœlestis eclipticus viii.," E. Heis (Cologne); "Die Fauna des Graptolithen-Gesteines," K. Haupt (Görlitz); "Bericht über die Beobachtung des Venus-Durchgangs vom 8ten December in Luxor," A. Auwers (Berlin) ; " Theorie der Wärme," translated from Prof. J. C. Maxwell by F. Neesen; "Das Nervensystem \&c., der Medusen," O. and R.' Hertwig (Leipzig)"; "Journal des Museums Godeffroy-A. Garret's Fische der Suidsee" (Hamburg); "Fungi italici authographice delineati," P. A. Saccardo (Berlin). The three last are very expensive works.

THE additions to the Zoological Society's Gardens during the past week inclucle three Common Rheas (Rhea americana) from South America, presented by:Mr. Frank Parish; four Water Ouzels (Cinclus aquaticus), British, presented by Mr. R. J. L. Price; a Hairy Tapir (Tapirus roulini) from Columbia, two Great-Billed Rheas (Rhea macrorhyncha), two Sulphury Tyrants (Pitangus sulphuratus) from. South America, received in ex change; two Chimpanzees (Troglodytes niger) from West Africa, deposited; two Bar-headed Geese (Anser incicus) from India, purchased; a Great Kangaroo (Macropus giganteus), two Wild Boars (Sues scrofa), two Wild Cats (Felis catus), born in the Gardens; two Geoffroy's Doves (Peristera geoffroii), seven Chilian Pintails (Dafila spinicauda), a Yellow-Legged Herring Gull (Larus leucophous), bred in the Gardens.

\section{THE FRENCH METEOROLOGICAL SERVICE}

$W E$ learn that $M$. Mascart has been appointed head of the meteorological bureau. $\mathrm{He}$ is professor in the Collége de France, his special subjects being light and electricity. $\mathrm{He}$ is author of a work in two volumes, on static electricity.

Last week we gave a brief sketch of the new organisation of the French meteorological service by the government, and tbis week we are able to publish a translation of the decree, from which it will be seen how much alive the French government is to the national importance of a complete meteorological service. How Article 2, referring to "Titular Meteorologists," "Adjoint Meteorologists," and "Assistant Meteoro. logists," must surprise our "Meteorological" Council! In France they actually insist upon meteorologists to do meteorological work and to advise upon meteorological matters.

Article $\mathrm{r}$. - The meteorological division of the Paris Observatory forms a distinct service, which takes the title of "Bureau Central Météorologique." This service comprises the study of the movements of the atmosphere, meteorological advertise. ments to the ports and to agriculture, the organisation of the meteorological observations, and of the regional or departmental commissions, the publication of their works, and the whole of the researches on meteorology or on climatology.

2. The meteorological service of France comprises titular meteorologists, adjoint meteorologists, and assistant meteorologists. The salary of the titular meteorologists varies from 3,000 to 10,000 francs. The adjoint meteorologists are divided into three classes, whose salaries yary from 2,500 to 5,000 francs. The assistant meteorologists are divided into two classes, whose salaries vary from $I, 500$ to 2,000 francs. This staff is distributed among the central bureau and the regional or departmental observatories, in proportion to the needs of these establishments.

3. The scientific staff of the central bureau comprises a titular meteorologist acting as director, two titular meteorologists placed under him, adjoint meteorologists, and assistant metcorologists. One of the adjoint or assistant meteorologists acts as secretary of the central bureau.

4. The director is charged with the general service of the establishment, the correspondence, the presentation to the minister of the proposed annual budget, the meteorological service, and a detailed account of the yearly expenses. He ought to secure the co-ordination and execution of the works which demand the concurrence of the different services placed under his orders, and see to the regularity of the publications. No order may be given without his authorisation.

5. The scientific works are divided as follows :-(1) Service of advertisements to the ports and to agriculture. (2) Service of the general movements of the atmosphere. (3) Service of climato. logy and of inspections. Each of the chiefs of the service remits monthly to the director a summary report on the progress of the works, and brings directly before the committee, instituted in the following article, the scientific questions of the service.

6 . The heads of the service meet each month, on a fixed day, under the presidency of the director. This committee may hold extraordinary meetings at the instance of the director.

7. The titular meteorologists and the director are nominated by decree, on the proposition of the minister, and after the advice of the council, to be spoken of afterwards. The adjoint and assistant metcorologists are appointed by orders after advice of the same council.

8. The heads of the regional meteorological observatories are placed under the authority of the director of the central bureau. Each of these officials addresses to the central bureau, under cover of the minister, the observations and works of his establishment. He proposes to the council, through the director of the central bureau, the advancement of the meteorologists under his orders.

9. The meteorological observatories and stations of every order will be visited ammually by the meteorologist of the central bureau charged with the service of climatology and inspections. They may also be visited by the director of the bureat or by a member of the council appointed for that purpose. In cases where the departments or towns contribute to the expenses of a meteorological observatory, the inspection will take place in company with the delegate of the general or municipal cotncil interested.

10. There is established beside the central meteorological bureau, a council composed of (I) A representative of each of the Ministries of Agriculture and Commerce, of Public Works, of War, Marine, Foreign and Home Affairs and of the Administration of Telegraph Lines; (2) Two delegates from the Ministry of Public Instruction; (3) Two members of the Academy of Sciences; (4) The director of the central bureau. The heads of the special service of the bureau are admitted to the council, with a consultative voice for questions which interest them. The members of the council are appointed for three years, by decree, on the proposal of the Ministry of Public Instruction. 
Ix. The council of the central burean will meet once every quarter on a fixed day. It may hold extraordinary meetings at the instance of the minister. The council gives its advice in the budget proposed by the director, on the construction of buildings or instruments intended for regional meteorological observations, on the collective investigations carried on in the various establishments, on the nominations and promotions of the officials, \&c.

I2. The president, vice-president, and the secretary of the council are appointed annually by the minister on the proposal of the council.

I3. The council holds a general meeting yearly at which may be present the heads of the central bureau and of the regional observatories, the delegates of the regional and departmental commissions, and three delegates of the French Meteorological Society.

A regulation deliberated in council and approved by the minister will determine the mode and number of the delegations.

This meeting will hear the report of the president and council on the work of the year, and, if there are any, the reports and memoirs of the heads of the observatories that receive subventions, and those of the delegates of the regional or departmental commissions. It will discuss the views submitted to it, and transmit them to the minister. The report of the president will be printed.

\section{UNIVERSITY AND EDUCATIONAL INTE LLIGENCE}

A Town meeting was held at Liverpool on Friday, the Mayor presiding, with the view of establishing a college for kigher education, so as to qualify for degrees in art, science, and other subjects at any of the universities.

LEYDEN.- - The university shows an attendance at present of 823 students, divided among the faculties as follows :- Law, 487 ; theology, 41 ; medicine, 184 ; philology, 58 ; science, 53 . The corps of professors numbers 47 .

AGRAM.-This young university is attended at present by 348 students, of whom but four are from countries outside Anstria.

\section{SOCIETIES AND ACADEMIES}

\section{LONDON}

Royal Society, May I6._Experimental Researches on the Electric Discharge with the Chloride of Silver Battery. Part II. The Discharge in Exhausted Tubes." By Warren De La Rue, M.A., D.C.L., F.R.S., and Hugo W. Miiller, Ph.D., F.R.S.

"Note on Legendre's Coefficients." By I. Todhunter, F.R.S.

May 23.- "Observations on Arctic Sea-water and Ice." By Dr. M@ss.-The paper consists of physical and chemical observations made during the Expedition of 1875.76 on polar ice and sea-water, and is accompanied by a tabulated statement of chlorine and specific gravity estimations; the latter made by the method devised by Mr. Buchanan of the Challenger. The author remarks that the low specific gravity of the Polar Sea $\left(\mathrm{r}^{\circ} 02467\right)$ indicates that even the deepest samples obtained had already received the dilution characteristic of outflowing polar currents. This low. specific gravity was maintained through the winter. The highest temperature observed in the deep stratum of dense warm water in Smith's Sound was below $32^{\circ}$, but since its specific gravity was above that of Atlantic water, the northward flowing current may have a slightly higher temperature at a greater depth. The disturbed proportion of sulphates to chlorides in polar waters is attributed to the littoral source of their dilution and to the difference in the behaviour of the sulphuric and chloric cryohydrates (rather than to absence of fucoidal plants or volcanic influence, as suggested by Forchhammer). A detailed description is given of a névé-like stratification in the polar ice, proving, in the author's opinion, that the stupendous floes met with by the recent, and many other expeditions, are due, not to progressive freezings of sea-water, or to the sliding up of thinner ice-fields, but to a perennial accumulation of polar precipitation. The stratification includes and overlies air-carried débris of crystalline rocks, chiefly quartz, augite, and magnetite.

The strata are often built upon a conglomerate formation (including salt-water Diatomacex) affording evidence of a lateral extension of the floating glacier (by the freezing together of fragments in fissures). The "blue-domed" floes belong to the outer zones of the polar ice-cap, where waste exceeds precipitation. Their undulating surfaces intersecting the horizontal stratification and pitted with the ice-dust left from the layers above, are the surface signs of the decay which finally restores polar precipitation to the ocean in the shape of the increased dilution of outflowing polar currents.

May 25.- "On the Equations of Circles." (Second Memoir.) By John Casey, LL.D., F.R.S., M.R.I.A., Professor_of Mathematics in the Catholic University of Ireland.

"Contributions to the Anatomy of the Central Nervous System in Vertebrate Animals. Part I. Ichthyopsida. Section I. Pisces. Subsection I. Teleostei." By Alfred Sanders, M.R.C.S. Communicated by Prof. Huxley, Sec.R.S.

Zoological Society, May 7.-F. D. Godman, F.Z.S., in the chair.-Mr. T. J. Parker read some notes on the stridulating organ of Palinurus vulgaris which had first been described by Dr. K. Möbius, but on whose observations Mr. Parker offered several criticisms.-A communication was read from Dr. F. Buchanan White, entitled "Contributions to a Knowledge of the Hemipterons Fauna of St. Helena, and Speculations on its Origin." In the first part of his paper the author, after briefly noticing what was known with regard to the fauna and flora of that remote and interesting oceanic island, and mentioning the various theories that had been brought forward to account for their origin, discussed the difficulties of the animals, and argued that they had evidently been derived at a remote period from the Palæarctic region by way of Madeira, the Canaries, and the Cape de Verde Archipelago. In the second part of his com. munication Dr. F. B. White described the Hemiptera collected in St. Helena by the late Mr. T. V. Wollaston, during the recent visit of that lamented naturalist to the island. The collection included thirty species, of which five were probably introduced; one appeared to be indigenous, but seemed identical with a European species, and the remaining twenty-four were regarded by the author as new and peculiar to the jsland. Seven new genera and one new sub-genus were created for the reception of ten of the species, the rest, with one exception, being referred to European genera. Specimens and drawings of details were exhibited in illustration of the paper.-Mr. P. L. Sclater, F.R.S., read some further remarks on Fulioula nationi, a species of duck from Western Peru, of which he had lately received a nearly adult male from Prof. Nation, the discoverer of the species.-Mr. A. G. Butler, F.Z.S., read the descriptions of a small collection of lepidoptera made at Kingston, Jamaica, by Mr. James J. Bowry.-Mr. Edgar A. Smith, F.Z.S., read a paper containing the description of three new land shells from Jamaica and Borneo.-A communication was read from $\mathrm{Mr}$. D. G. Elliot, F.Z.S., containing a memoir on the fruit pigeons of the genus Ptilopus. Mr. Elliot recognised seventy-one species of this genus.

Meteorological Society, May I7.-Mr. C. Greaves, F.G.S., president, in the chair.-A. H. J. Crespi, B.A., M.R.C.S., Rev. David Lamplugh, William Morris, M. Inst. C.E. James Muir, M. Inst. C.E., and Miss E. A. Dymond, were elected Fellow's of the Society.-The following papers were read :- On the daily inequality of the barometer, by W. Rundell, F.M.S.-Meteorology of Mozufferpore, Tirhoot, for the year I 877 , by C. N. Pearson, F.M.S. - Note on the great rainfall of April ro-I I, as recorded at the Royal Observatory, Greenwich, by William Ellis, F.R.A.S.--Observations of Ser Temperature at slight depths, by Capt. W. F. Caborne, F.M.S.

Anthropological Institute, April 3oth.-Major-General A. Lane Fox, F.R.S., vice-president, in the chair.-Mr. Francis Galton, F.R.S., read a paper on composite portraits, made by combining those of various persons into a single resultant fioure (NATuRE, p.97).- The Director read a paper by Mr. C. Staniliand Wake on the origin of the classificatory system of relationships used among primitive people. After criticising Mr. Morgan's explanation of the classificatory system as having originated in the practice of marriage among consanguinei, Mr. Wake proceeded to show that the social condition of the Polynesian peoples, who possessed the simplest form of that system was inconsistent with the origin assigned to it by Mr. Morgan. The 